\title{
FOOD PLANT SELECTION BY A GENERALIST HERBIVORE: THE MOOSE ${ }^{1}$
}

\author{
GARY E. BeLovSKY ${ }^{2}$ \\ Society of Fellows, Harvard University, Cambridge, Massachusetts 02138 USA and \\ Department of Zoology, University of Washington, Seattle, Washington 98195 USA
}

\begin{abstract}
A model of food plant selection by a generalist herbivore was developed. The model was designed to predict the species composition of the diet of an herbivore based upon the joint probabilities of whether or not an individual of a plant species satisified two threshold values: some nutritional minimum and a size limit (both minimum and maximum), and the probability that it was encountered while foraging. The model was tested using moose (Alces alces) at Isle Royale National Park, Michigan, USA. Initially the threshold values for food selection were determined empirically from the moose's observed behavior, but these empirical values were later shown to be based upon time-energy considerations. Although the model satisifed some of the criteria of optimal foraging contingency models, it appeared that the perfect knowledge assumption was not met. Rather, moose appeared to utilize a strategy of risk aversion.
\end{abstract}

Key words: foraging strategies; herbivory; Isle Royale; moose; plant-animal interactions.

\section{INTRODUCTION}

Herbivores have long been known to demonstrate preferences for different plant species and individual plants within a species. Also, the average food plant quality (i.e., protein, sugars, etc.) selected by different herbivores has been shown to be greater than the average found in the environment (Swift 1948, Bissell et al. 1955, Bissell and Weir 1957, Radwan and Campbell 1968, Radwan 1972, Radwan and Crouch 1974). The moose (Alces alces), a generalist herbivore, had preferences for different plant species (Belovsky and Jordan 1978) and selected its diet to maximize net energy intake (Belovsky 1978). Plants fed upon by moose were examined in this study to determine whether a set of minimum plant quality values were selected by moose, whether these values predicted preferences for plants, and whether these were consistent with optimal foraging theory (Schoener 1971, Pyke et al. 1977).

Using linear programming, three food classes (deciduous leaves, forbs and aquatic macrophytes), and constraints for mineral requirements, rumen capacity and available feeding time, a model of moose optimal foraging (Belovsky 1978) demonstrated that moose consumed aquatic plants for sodium and deciduous leaves and forbs for energy during summer at Isle Royale National Park, Michigan. Moose preferences for aquatic species were highly correlated with plant sodium concentrations $\left(r^{2}=.98, P \leqslant .01, N=6\right.$ : Belovsky and Jordan, in press). In this paper, the analysis of food plant preferences was restricted to plants sought for energy: deciduous leaves and forbs in summer and deciduous and coniferous twigs in winter.

\footnotetext{
${ }^{1}$ Manuscript received 3 April 1980; accepted 28 May 1980.

${ }^{2}$ Present address: School of Natural Resources, University of Michigan, Ann Arbor, Michigan 48109 USA.
}

Forbs were excluded from the analysis of summer feeding because forbs accounted for only $9 \%$ of the terrestrial diet and deciduous leaves were the main energy source for moose (Belovsky 1978). Another reason for not including forbs was that the necessary nutrient content measurements were unavailable. This does not imply that moose did not require nutrients other than energy, but either other types of plants supplied the nutrients and were consumed for that purpose (i.e., sodium in aquatic plants), or the nutrient was abundant enough in most plants not to require special attention while feeding (i.e., protein).

The moose optimal foraging model constraints for rumen capacity and available feeding time (Belovsky 1978) suggested that seasonal preferences of plants consumed for energy might be related to some seasonal minimum digestibility and seasonal minimum and/or maximum leaf or twig size, beyond which the time-energy expenditure to crop the plant became too great in relation to the moose's energy demands and feeding time availability. Knowing the plant species preferred by moose, their mean nutrient contents (protein plus ash) and standard deviations, and the percentages of plants within each species fed upon by moose, a minimum nutrient content was computed for the most preferred species such that the percentage of all plants with a greater nutrient value equaled the percentage of plants within each species fed upon. It was used successfully to predict the percentages of plants chosen from other preferred species. The minimum nutrient value was converted to a minimum digestibility value using an empirically determined digestibility-nutrient relationship. The minimum and/or maximum item sizes selected by moose were determined by observing moose feed. Finally, the availability of plants with quality and item size values satisfying the moose's selection criteria 
TABLE 1. The mean summer and winter nutrient values (mineral + protein) and standard deviations (in parentheses) for various plant species at Isle Royale (D. Botkin and P. Jordan, personal communication) and the percentage of plants utilized by moose in summer and winter are presented. The number of plants examined to determine percent utilization appears in parentheses after the latter measured values. Also presented are the nutrient threshold model's predicted moose utilization (see text). The term 'test' appears under the predicted plant utilization columns for the most preferred species because the observed utilizations for these species were used to predict the nutritional threshold and consequently could not have a predicted value. Nonpreferred plant species are marked with an asterisk.

\begin{tabular}{|c|c|c|c|c|c|c|}
\hline \multirow[b]{3}{*}{ Species name } & \multirow{2}{*}{\multicolumn{2}{|c|}{$\begin{array}{c}\text { Mean nutrient values } \\
\text { (percent ash }+ \text { crude protein) }\end{array}$}} & \multicolumn{4}{|c|}{$\begin{array}{c}\text { Plant utilization } \\
\text { (percent of plants with leaves or twigs removed) }\end{array}$} \\
\hline & & & \multicolumn{2}{|c|}{ Summer } & \multicolumn{2}{|c|}{ Winter } \\
\hline & Summer & Winter & Observed & Predicted & Observed & Predicted \\
\hline A) Sorbus americana & $27.9(3.5)$ & $8.2(1.5)$ & $57.0(260)$ & test & $76.5(221)$ & test \\
\hline B) Betula papyrifera & $25.8(3.5)$ & $7.6(0.6)$ & $37.0(68)$ & 34 & $8.5(28)$ & 65.5 \\
\hline C) Diervilla lonicera & $24.9(2.0)$ & & $13.0(87)$ & 14 & & \\
\hline D) Amelanchier sp. & $26.0(3.5)$ & & & 35 & $69.2(13)$ & 68.5 \\
\hline E) Acer spicatum & $26.6(3.5)$ & $7.8(0.9)$ & $48.0(192)$ & 42 & $77.5(204)$ & 70.9 \\
\hline F) Acer saccharum & $27.9(2.5)$ & & $46.0(13)$ & 59 & & \\
\hline G) Cornus stolonifera & $27.9(1.7)$ & & $44.0(16)$ & 63 & & \\
\hline H) Prunus pensylvanica & $27.4(7.5)$ & & $50.0(10)$ & 50 & & \\
\hline I) Rubus idaeus* & $25.7(3.5)$ & & tr. (121) & 32 & & \\
\hline J) Alnus rugosa* & $26.0(2.7)$ & & tr. $(84)$ & 31 & & \\
\hline K) Rubus parviflorus* & $25.1(2.1)$ & & tr. $(183)$ & 15 & & \\
\hline L) Sambucus pubescens* & $31.5(5.5)$ & & tr. (7) & 76 & & \\
\hline M) Corylus cornuta* & $28.8(2.1)$ & $8.3(1.1)$ & $14.0(21)$ & $75(6)$ & $80.8(26)$ & 83.7 \\
\hline N) Betula alleghaniensis* & $28.9(2.5)$ & $9.5(1.4)$ & $31.0(108)$ & 74 (13) & $93.6(110)$ & 93.6 \\
\hline O) Lonicera canadensis* & $21.1(2.7)$ & & $1.0(70)$ & 1 & & \\
\hline P) Thuja occidentalis & $12.0(0.4)$ & $13.3(1.3)$ & $0(54)$ & 0 & $93.0(14)$ & 99.9 \\
\hline Q) Abies balsamea & $24.3(2.4)$ & $10.4(1.3)$ & $0(882)$ & 5 & $89.2(37)$ & test \\
\hline R) Picea glauca* & $10.6(2.4)$ & $9.1(0.4)$ & $0(33)$ & 0 & $79.7(30)$ & 13.3 \\
\hline
\end{tabular}

was shown to determine absolute intake of preferred species.

The analysis in this paper dealt solely with preferred plant species. Using a $\chi^{2}$ contingency table, a preferred plant was defined as a plant whose proportional composition of the moose diet was not significantly less, statistically, than its proportional composition in the environment. However, minimum plant quality values were used to determine whether nonpreferred plant species satisfied the above criteria or whether other factors, such as toxicity, might be necessary to explain the moose's aversion for these species. This permitted a preliminary comparison of a simple hypothesis of food plant selection on the basis of plant quality with more complex hypotheses based upon balancing herbivore nutritional demands and biochemical detoxification abilities (Freeland and Janzen 1974, Westoby 1974).

\section{METHODS}

The data used in this study were collected at Isle Royale National Park, Michigan, between 1972 and 1974. Two distinct forest types were studied: an upland forest ('Yellow Birch') and a lowland forest ('Coastal'). Both regions were fully described in Belovsky and Jordan (1978).

Summer moose feeding data (diet, leaf availability, in vitro digestibility for several species, and moose preferences) were presented by Belovsky and Jordan (1978). Moose preferred Sorbus americana, Acer spi- catum, Diervilla lonicera, Prunus pensylvanica, Acer saccharum, Betula papyrifera, and Cornus stolonifera (Belovsky and Jordan 1978); these species were noted as preferred in all tables.

One hundred $2 \mathrm{~m}$ radius plots were examined to determine the percentage of plants of each species which had leaves removed by moose in summer (Table 1). The plots were located at $100-\mathrm{m}$ intervals along a $1-\mathrm{km}$ transect. The starting point of each transect was randomly chosen along an east-west axis of the study area and the transects crossed the area in a northsouth axis. Plants were examined only to a height of $2.8 \mathrm{~m}$ above the ground, the maximum reach of adult moose. Plants were identified as fed-upon if petioles without leaves, or scars left by the removal of petioles from twigs were found. Moose-removed leaves could be separated from hare- and insect-removals, because hare left a petiole cut at a neat $45^{\circ}$ angle, and insects did not consume the entire leaf.

The minimum leaf size selected by moose during summer was measured by observing feeding moose at distances of 3-15 $\mathrm{m}$ through binoculars. At this distance, the leaves selected by moose were clearly observed. The observer selected a leaf with an identical petiole diameter to the moose-removed leaf from a plant of the same species. Petiole diameter was measured with calipers. The collected leaves were ovendried $\left(80^{\circ} \mathrm{C}, 48 \mathrm{~h}\right)$ and weighed; the smallest leaf collected was considered the minimum leaf size selected by moose. For all species but Sorbus americana, the 
TABLE 2. The mean sizes of leaves and twigs available to Isle Royale moose from different plant species in summer and winter are presented along with the standard deviations (in parentheses). Also presented are the minimum and maximum sizes moose were observed to consume. The average item size consumed by moose was predicted from the available item sizes, assuming moose chose leaves or twigs on the basis of minimum and maximum sizes, and is presented for comparison with the observed mean item sizes selected by moose. The percentages following the predicted item sizes are the predicted proportions of plants of each species having mean leaf sizes greater than the minimum or less than the maximum item sizes selected by moose. A dotted line (. . ) indicates that no data were obtained for that species. Nonpreferred plant species are designated with an asterisk.

\begin{tabular}{|c|c|c|c|c|c|c|c|c|c|}
\hline \multirow[b]{3}{*}{ Species name } & \multicolumn{4}{|c|}{$\begin{array}{c}\text { Summer } \\
\text { Leaf size mass ( } \mathrm{g} \text { dry mass) }\end{array}$} & \multicolumn{5}{|c|}{$\begin{array}{c}\text { Winter } \\
\text { Twig size (diameter in } \mathrm{mm} \text { ) }\end{array}$} \\
\hline & \multirow{2}{*}{$\begin{array}{c}\vec{x} \\
\text { observed } \\
\text { on plants } \dagger\end{array}$} & \multirow{2}{*}{$\begin{array}{l}\text { Mini- } \\
\text { mum } \\
\text { con- } \\
\text { sumed } \neq\end{array}$} & \multicolumn{2}{|c|}{$\begin{array}{c}\bar{x} \text { consumed } \\
\text { by moose }\end{array}$} & \multirow[b]{2}{*}{$\begin{array}{c}\bar{x} \text { observed } \\
\text { on plants }-N \Phi\end{array}$} & \multicolumn{2}{|c|}{$\begin{array}{r}\text { Consumed } \\
\text { by moose }\end{array}$} & \multicolumn{2}{|c|}{$\begin{array}{c}\bar{x} \text { consumed } \\
\text { by moose }\end{array}$} \\
\hline & & & Predicted & $\begin{array}{c}\text { Ob- } \\
\text { served } \neq\end{array}$ & & Min & $\operatorname{Max}$ & Predicted & $\begin{array}{c}\text { Ob- } \\
\text { served }\end{array}$ \\
\hline A) Sorbus americana & $.27(.17)$ & .23 & $.41(58 \%)$ & .43 & $6.1(1.6)-63$ & 1.6 & 6.2 & $5.1(53 \%)$ & 4.4 \\
\hline B) Betula papyrifera & $.05(.02)$ & .10 & $.11(1 \%)$ & .13 & $3.9(1.0)-28$ & .3 & 3.9 & $3.1(46 \%)$ & 2.7 \\
\hline C) Diervilla lonicera & $.13(.05)$ & .10 & $.15(70 \%)$ & $\ldots$ & & & & & \\
\hline D) Amelanchier sp. & $.13(.07)$ & .10 & $.16(63 \%)$ & .. & $3.2(.8)-12$ & 1.5 & 2.8 & $2.4(29 \%)$ & 2.2 \\
\hline E) Acer spicatum & $.11(.04)$ & .10 & $.13(52 \%)$ & .16 & $4.5(1.0)-33$ & 1.8 & 4.4 & $3.7(46 \%)$ & 2.8 \\
\hline F) Acer saccharum & $.22(.08)$ & .10 & $.22(93 \%)$ & $\ldots$ & & & & & \\
\hline G) Cornus stolonifera & $.14(.04)$ & .10 & $.14(82 \%)$ & & & & & & \\
\hline H) Rubus idaeus* & $.13(.12)$ & .10 & $.20(60 \%)$ & .. & & & & & \\
\hline I) Alnus rugosa* & $.24(.11)$ & .10 & $.34(72 \%)$ & . & & & & & \\
\hline J) Rubus parviflorus* & $.54(.23)$ & .10 & $.55(97 \%)$ & . & & & & & \\
\hline K) Sambucus pubescens* & $.54(.20)$ & .10 & $.54(99 \%)$ & . & & & & & \\
\hline L) Corylus cornuta* & $.14(.05)$ & .10 & $.15(76 \%)$ & .15 & $3.2(.7)-12$ & 1.9 & 2.8 & $2.5(24 \%)$ & 2.4 \\
\hline M) Betula alleghaniensis* & $.09(.05)$ & .10 & $.13(43 \%)$ & .10 & $4.4(1.1)-46$ & .9 & 3.8 & $3.2(29 \%)$ & 3.0 \\
\hline N) Lonicera canadensis* & $.05(.03)$ & .10 & $.11(3 \%)$ & .10 & & & & & \\
\hline O) Thuja occidentalis & & & & & $5.4(1.9)-16$ & 1.5 & 2.8 & $2.4(7 \%)$ & 2.0 \\
\hline P) Abies balsamea & & & & & $2.2(1.0)-45$ & 1.0 & 3.3 & $2.2(74 \%)$ & 1.9 \\
\hline
\end{tabular}

$\dagger N=16$ plants per species

$\ddagger N=1000$ leaves per species.

$\S N=100$ twigs for each species.

" $N=100$ twigs for each species.

I $N=$ plants per species.

minimum size was $0.10 \mathrm{~g}$ and for Sorbus, $0.23 \mathrm{~g}$. This difference was a result of tree form; all species but Sorbus positioned leaves at intervals along branches, while Sorbus with its pinnately compound leaves produced a monolayer as a result of moose herbivory, thus making further cropping more difficult. The mean masses of species' leaves selected by moose were computed from the sum of all leaves weighed which matched those consumed by moose (Table 2).

Winter moose-feeding data were measured in 102 $\mathrm{m}$ radius plots which were established in the same manner as summer plots (see above). During the fall, all twigs were inventoried on the plots and 659 twigs of different species were tagged. All tagged twigs were measured for length and diameter at their junction with a main branch. The following spring the plots were reinventoried to measure the effects of moose winter feeding. Twigs within $2.8 \mathrm{~m}$ of the ground, the reach of adult moose, were considered available. As with leaf-removals, moose-removals were identifiable because insects did not feed on twigs and hare left a $45^{\circ}$ angle cut. These measurements provided data on twig availability (Table 3), diet (Table 4), the percentage of plants of each species with twigs removed (Table 1), and moose preferences. Moose preferred Sorbus americana, Acer spicatum, Amelanchier sp., Corylus cornuta and Abies balsamea in winter; these species were noted as preferred in all tables.

The diameters of moose-browsed twigs in the winter plots were measured at the point of consumption. Diameter was used to measure twig size, because this measurement could be made after a moose had fed upon a twig. Diameter/dry mass regressions were used to compute twig masses. The mean sizes of twigs consumed by moose were computed from this data (Table 2). The minimum and maximum twig sizes were measured as the average of the smallest and largest $10 \%$ of moose-consumed twigs (Table 2).

Isle Royale plant nutrient content was measured using atomic absorption spectrophotometry for mineral analysis of ash and the Kjeldahl technique for crude protein analysis (D. Botkin and P. Jordan, personal communication). Plant nutrient values were presented (Table 1) as the sum of percent ash and crude protein; this unorthodox measure was utilized because, of other single nutrient values (protein, sodium, magnesium, potassium, calcium and phosphorus) and combinations of these values, only this measure was highly correlated with moose digestibility (see Discussion). 
TABLE 3. The relative availability of species is presented in terms of the number of leaves present for deciduous species in summer (excluding Rubus idaeus, Rubus parviflorus, and a number of rare species) (Belovsky and Jordan 1978), and the number of twigs present for both deciduous and coniferous species in winter. Winter, 1973, in the Yellow Birch forest was the only year for which data on availability of twigs were collected. The $n$ values refer to thousands of leaves or twigs counted. A dotted line (. . ) indicates that no data were obtained for that species.

\begin{tabular}{|c|c|c|c|c|c|c|c|}
\hline & & \multicolumn{4}{|c|}{ Yellow Birch } & \multicolumn{2}{|c|}{ Coastal } \\
\hline & & \multirow{2}{*}{$\frac{1972}{\text { Summer }}$} & \multicolumn{2}{|c|}{1973} & \multirow{2}{*}{$\frac{1974}{\text { Summer }}$} & \multirow{2}{*}{$\frac{1972}{\text { Summer }}$} & \multirow{2}{*}{$\frac{1974}{\text { Summer }}$} \\
\hline & & & Summer & Winter & & & \\
\hline $\begin{array}{l}n \text { leaves: } \\
\text { twigs: }\end{array}$ & $\begin{array}{l}n= \\
n=\end{array}$ & 73 & 22 & 2 & 4 & 20 & 4 \\
\hline \multicolumn{2}{|c|}{$\begin{array}{l}\text { Sorbus americana } \\
\text { Betula papyrifera }\end{array}$} & $\begin{array}{c}8.0 \% \\
11.1 \\
4.2\end{array}$ & $\begin{array}{l}6.8 \% \\
2.3 \\
3.9\end{array}$ & $\begin{array}{c}22.3 \% \\
7.1 \\
\ldots\end{array}$ & $\begin{array}{l}5.8 \% \\
2.7 \\
1.3\end{array}$ & $\begin{array}{l}10.9 \% \\
42.5 \\
.6\end{array}$ & $\begin{array}{l}8.2 \% \\
10.6 \\
\ldots\end{array}$ \\
\hline \multicolumn{2}{|c|}{ Amelanchier sp. } & $\ldots$ & & 1.4 & & & \\
\hline \multicolumn{2}{|c|}{ Acer spicatum } & 12.1 & 18.0 & 20.8 & 51.7 & 13.1 & 40.7 \\
\hline \multicolumn{2}{|c|}{ Acer saccharum } & .3 & .5 & $\ldots$ & $\cdots$ & $\ldots$ & $\ldots$ \\
\hline \multicolumn{2}{|c|}{ Alnus rugosa } & 1.6 & 9.0 & $\cdots$ & 5.3 & $\cdots$ & $\cdots$ \\
\hline \multicolumn{2}{|c|}{ Corylus cornuta } & 1.6 & 1.9 & .8 & .6 & $\cdots$ & $\ddot{z}$ \\
\hline \multicolumn{2}{|c|}{$\begin{array}{l}\text { Betula alleghaniensis } \\
\text { Lonicera canadensis }\end{array}$} & $\begin{array}{l}48.8 \\
12.2\end{array}$ & $\begin{array}{l}45.9 \\
11.8\end{array}$ & 33.1 & $\begin{array}{l}20.9 \\
11.8\end{array}$ & $\begin{array}{r}.4 \\
32.5\end{array}$ & $\begin{array}{r}3.2 \\
37.4\end{array}$ \\
\hline \multicolumn{2}{|c|}{ Thuja occidentalis } & $\cdots$ & $\ldots$ & 7.2 & $\ldots$ & $\ldots$ & $\ldots$ \\
\hline \multicolumn{2}{|c|}{ Abies balsamea } & $\ldots$ & $\ldots$ & 7.2 & $\ldots$ & $\ldots$ & $\ldots$ \\
\hline
\end{tabular}

The distribution of leaf sizes for 16 plant species was determined by defoliating plants, counting each plant's leaves, weighing the oven-dried leaves from each plant, and dividing the mass by the number of leaves, enabling the computation of a species' mean leaf mass and standard deviation (Table 2). The distribution of twig sizes was measured from the diameters of marked twigs in the winter plots (see above) as the mean and standard deviation for each species (Table 2).

\section{RESUlts}

Plants that moose preferred to feed upon were assumed to have the highest available nutrient content. Using the mean nutrient content and standard deviation of the most preferred species in the standard-normal distribution model, the minimum nutrient value selected by moose $(N)$ was computed such that the proportion of all nutrient values equal to or greater than $N$ equalled the proportion of plants from a particular species that were utilized by moose. Sorbus

TABLE 4. The comparison of the predicted and observed moose diets includes two forest types in which data were collected over $3 \mathrm{yr}$. The observed summer leaf diet information came from Belovsky and Jordan (1978); and the observed winter twig diet information was collected from the Yellow Birch forest during the winter of $1973-74(n=691$ twigs $)$. $P$ refers to the predicted diet and $O$ is the observed diet (percentage). For summer, the diet was based upon biomass consumed, whereas the winter diet was based on the number of twigs of each species consumed. A dotted line (...) indicates that no data were obtained for that species.

\begin{tabular}{|c|c|c|c|c|c|c|c|c|c|c|c|c|}
\hline & \multicolumn{8}{|c|}{ Yellow Birch } & & & & \\
\hline & & & \multicolumn{4}{|c|}{1973} & & & \multicolumn{4}{|c|}{ Coastal } \\
\hline & \multicolumn{2}{|c|}{1972} & \multicolumn{2}{|c|}{ Summer } & \multicolumn{2}{|c|}{ Winter } & \multicolumn{2}{|c|}{1974} & \multicolumn{2}{|c|}{1972} & \multicolumn{2}{|c|}{1974} \\
\hline & $P$ & $O$ & $P$ & $O$ & $\boldsymbol{P}$ & $O$ & $P$ & $O$ & $P$ & $O$ & $P$ & $O$ \\
\hline Sorbus americana & 58.4 & 60.6 & 50.0 & 54.7 & 27.7 & 32.7 & 33.5 & 33.0 & 76.0 & 78.3 & 46.9 & 61.2 \\
\hline Betula papyrifera & .2 & 2.9 & .1 & 5.2 & 6.6 & 3.8 & .1 & 4.1 & 5.4 & 2.4 & .1 & 0 \\
\hline Diervilla lonicera & 3.1 & 3.9 & 3.1 & 1.9 & $\ldots$ & $\cdots$ & .8 & 1.1 & .5 & .3 & $\ldots$ & $\ldots$ \\
\hline Amelanchier sp. & & & & & .9 & 1.4 & & & & & & \\
\hline Acer spicatum & 17.9 & 20.4 & 26.3 & 27.2 & 20.8 & 23.9 & 59.4 & 55.2 & 18.1 & 15.4 & 49.1 & 37.0 \\
\hline Acer saccharum & 2.0 & 4.7 & 3.1 & .7 & $\ldots$ & $\ldots$ & $\cdots$ & $\ldots$ & $\ldots$ & $\ldots$ & $\ldots$ & $\ldots$ \\
\hline Corylus cornuta & .5 & .8 & .7 & 1.2 & .5 & 1.1 & .1 & 1.1 & & $\ldots$ & $\ldots$ & $\ldots$ \\
\hline Betula alleghaniensis & 17.9 & 6.6 & 17.0 & 9.1 & 27.5 & 27.8 & 6.1 & 5.7 & .1 & 3.6 & .9 & 1.9 \\
\hline Lonicera canadensis & 0 & 0 & 0 & 0 & & & 0 & 0 & 0 & 0 & 0 & 0 \\
\hline Thuja occidentalis & $\cdots$ & $\cdots$ & $\cdots$ & $\cdots$ & 1.5 & 2.8 & $\cdots$ & $\cdots$ & $\cdots$ & $\cdots$ & $\cdots$ & $\cdots$ \\
\hline Abies balsamea & $\cdots$ & $\cdots$ & $\cdots$ & $\cdots$ & 14.5 & 6.6 & $\cdots$ & $\cdots$ & $\cdots$ & $\cdots$ & $\cdots$ & $\cdots$ \\
\hline $\begin{array}{l}\% \text { of observed diet } \\
\text { composed of these species }\end{array}$ & \multicolumn{2}{|c|}{99.3} & \multicolumn{2}{|c|}{94.7} & \multicolumn{2}{|c|}{99.0} & \multicolumn{2}{|c|}{97.0} & \multicolumn{2}{|c|}{99.3} & \multicolumn{2}{|c|}{96.9} \\
\hline
\end{tabular}


americana was the most preferred species for summer leaves $(N=27.3 \%)$ and winter deciduous twigs $(N=$ 7.3\%), while Abies balsamea was the most preferred species for winter coniferous twigs $(N=8.8 \%)$.

The empirically determined $N$ values for the most preferred species were used with the mean nutrient values and standard deviations of the other preferred species in the standard-normal distribution model to predict the proportions of their plants fed upon by moose (Table 1). Comparison of the predicted and observed plant utilizations (Table 1) indicated that moose might have selected for a minimum nutrient value in preferred plants (overall: $r^{2}=.85, n=9, P \leqslant .05$; summer: $r^{2}=.71, n=6, P \leqslant .05$; winter: $r^{2}=.66$, $n=3$, ns).

The mean edible size of a leaf or twig from each preferred species consumed by moose was predicted. This prediction was made using the observed distribution of leaf and twig sizes available to moose and the observed minimum and maximum leaf and twig sizes selected for each preferred plant species in the standard-normal distribution model. The computation was possible because all parameters were measured independently of each other. Close agreement was found between the predicted and observed mean sizes of leaves and twigs consumed by moose (Table 4 overall: $r^{2}=.99, n=8, P \leqslant .05$; summer: $r^{2}=.99$, $n=3, P \leqslant .05$; winter: $r^{2}=.95, n=5, P \leqslant .05$ ), indicating that moose might have an item size criterion in their food choice.

\section{Discussion}

\section{Selection of nonpreferred plants}

The possibility of minimum nutrient and item size criteria for the selection of preferred plant species by moose suggested that the same criteria might apply to nonpreferred plants.

The means and standard devaitions of nutrient contents for nonpreferred plant species (using the estimated minimum nutrient values selected by moose $(N))$ were used in the normal distribution model to determine if there was agreement between predicted and observed utilization (Table 1). Of 10 nonpreferred summer plant species studied, the utilization of only 4 species was closely predicted (within 10\%). (Predicted: Thuja occidentalis, Abies balsamea, Picea glauca and Lonicera canadensis; not predicted: $R u$ bus idaeus, Rubus parviflorus, Alnus rugosa, Sambucus pubescens, Corylus cornuta and Betula alleghaniensis.) For four nonpreferred winter plant species studied, the utilization of three species was closely predicted (Betula papyrifera, Betula alleghaniensis and Thuja occidentalis), and one species was not predicted (Picea glauca). The observed utilization of the seven nonpreferred plant species which were not predicted by the nutrient content hypothesis was always less than the predicted utilization value,

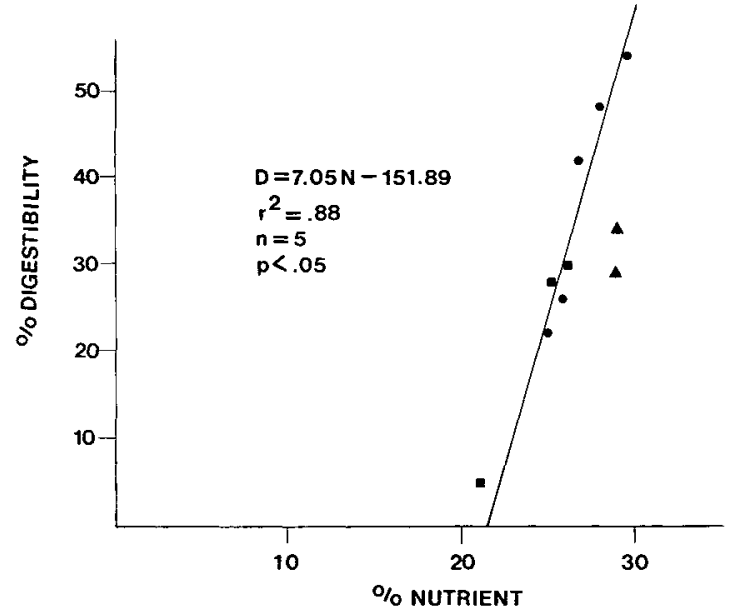

FIG. 1. A regression of in vitro dry matter digestibility, using moose rumen inocula, against the summer food-plant's nutrient content (mineral + protein as a percentage of dry mass). The plants denoted by circles are those preferred by moose and are the values used in the regression. Similar results have been noted by others (Short et al. 1974, Robbins and Moen 1975). The other points were not included in the regression because they represent plant species that are not fed upon preferentially (triangles) and those not fed upon at all (squares). The data on digestibility and preference comes from Belovsky and Jordan (1978).

suggesting that factors other than nutrient content might be important in reducing their utilization.

When the in vitro dry matter digestibility values for preferred plant species' summer leaves (Belovsky and Jordan 1978) were plotted against their nutrient contents (circles: Fig. 1), a very good relationship was found $\left(r^{2}=.88, n=5, P \leqslant .05\right)$. This indicated that the minimum nutrient content sought by moose might be related to a minimum required digestibility.

The in vitro dry matter digestibilities for three nonpreferred summer species were not found to be significantly different from the preferred plant digestibility-nutrient regression (squares: Fig. 1). One species, Lonicera canadensis, was utilized by moose as predicted by the minimum nutrient hypothesis; however, the other two species, Alnus rugosa and Rubus parviflorus, although predicted to be heavily used by moose, were almost never eaten. This suggested that while $L$. canadensis was not preferred because of its low nutrient content, factors other than nutrient content may have led to the exclusion of $A$. rugosa and $R$. parviflorus from the moose's diet.

Possibly $A$. rugos $a$ and $R$. parviflorus were toxic to moose; both were known to contain tannins (D. Rhoades, personal communication) and $R$. parviflorus contained cardiac glycosides (Pammel 1911, Kingsbury 1964). Other species which contained sufficient nutrient content to be heavily utilized by moose, but were almost never consumed, were known to be potentially toxic (Rubus idaeus, tannins; and 
Sambucus pubescens, kills birds and mammals, Pammel 1911, Kingsbury 1964), or possessed thorns or stiff needles ( $R$. idaeus, $P$. glauca). This, however, provided a circular definition of toxic plants since many preferred plants also contained compounds which were suspected of being toxic (cyanide-Sorbus americana, Prunus sp.; tannins and quinine-Salix sp.; Pammel 1911, Kingsbury 1964). Therefore, while some plants were utilized in a manner consistent with the minimum nutrient hypothesis, others were not. Furthermore, the plants not in agreement with the nutrient hypothesis were essentially never consumed by moose (utilization $\leqslant 1 \%$ ), even though they possessed a high nutrient content, indicating that other factors were important in determining moose utilization.

Two of the summer nonpreferred plant species which did not fit the nutrient hypothesis had digestibilities significantly less than the preferred plant digestibility-nutrient regression, but were still heavily utilized by moose (Betula alleghaniensis and Corylus cornuta: triangles, Fig. 1). The utilization of these two nonpreferred species was found to agree with the nutrient hypothesis, if: (1) given their measured in vitro digestibilities, their mean nutrient contents were reduced to the nutrient contents expected from the preferred plant digestibility-nutrient regression, and (2) their standard deviations of nutrient content were rescaled by the ratio of the expected mean nutrient content to the measured value (Table 1).

One of these two species, B. alleghaniensis, was known to contain methylsalicylate (Pammel 1911, Kingsbury 1964) which reduced the fermentation rate of rumen microorganisms, the moose's means of digestion (Longhurst et al. 1968). Therefore, it appeared likely that $B$. alleghaniensis and $C$. cornuta might contain compounds which inhibited digestion; thus the scaling of their nutrient parameters to their reduced digestibility placed their utilization in agreement with the nutrient hypothesis.

When all preferred and nonpreferred plant species which were utilized $<1 \%$ (essentially never consumed by moose) were dropped from the analysis, it was found that the nutrient hypothesis explained $80 \%$ of the variance in utilization of summer plants $(n=9)$ and $93 \%$ for winter plant utilization $(n=6)$. This suggested that the nutrient hypothesis, when reduced digestibility for nonpreferred species was taken into account predicted the utilization of plants which the moose included in its diet. However, there remained a set of plants whose exclusion from the diet could not be predicted by the nutrient hypothesis. Although the determination of which plant species should not be utilized depended upon factors in addition to nutrient content, once moose 'decided' to utilize a species the intensity of utilization appeared to be dependent upon the nutrient content hypothesis.

The item size criteria found for preferred plants successfully predicted the mean item sizes selected from nonpreferred plant species without any of the complications found with the nutrient criterion (summer: nonpreferred, $r^{2}=75, n=3$, ns; all species, $r^{2}=$ $.97, n=6, P \leqslant .05$; winter: nonpreferred, $r^{2}=.97$, $n=3$, ns; all species, $r^{2}=.94, n=8, P \leqslant .05$ ).

\section{Predicting a moose's diet}

As discussed above, certain plant species appeared to be excluded from a moose's diet (utilization $<1 \%$ ) and their exclusion did not appear to be dependent upon nutrient content. If these plant species were deleted from all further analysis (Rubus parviflorus, $R \mathbf{u}$ bus idaeus, Alnus rugosa, Sambucus pubescens, Picea glauca, and only in summer: Abies balsamea, and Thuja occidentalis), the question could be examined: how much of a moose's diet should be composed of a species, once the moose has 'decided' to utilize the species?

First, the proportion of consumable species $i$ 's plants which satisfied the nutrient criterion also represented the probability $\left(P_{N i}\right)$ that an individual plant of species $i$ was acceptable to a moose on the basis of its nutrient content (Table 1). Second, the proportion of consumable species $i$ 's leaves or twigs which satisfied the item size criteria represented the probability $\left(P_{S i}\right)$ that an individual plant of species $i$ was acceptable to a moose on the basis of its leaf or twig sizes (Table 2). Third, the relative abundance of consumable species $i$ represented the probability $\left(P_{F i}\right)$ that a moose encountered an individual plant of species $i$ (Table 3).

The probability $\left(P_{A i}\right)$ that a given plant encountered by a moose was of consumable species $i$ and had acceptable nutrient content and item size equaled:

$$
\boldsymbol{P}_{A i}=\boldsymbol{P}_{\boldsymbol{N} i} \boldsymbol{P}_{F i} \boldsymbol{P}_{S i},
$$

and the proportion of species $i$ in the diet equaled:

$$
\frac{P_{.1 i}}{\sum_{i} P_{.1 i}}
$$

For summer leaves, the predicted and observed diets agreed very well in five different study site-year combinations (Table 4: $r^{2}=.96, n=36, P \leqslant .01$ ). The predicted and observed twig diets also agreed quite well (Table $4, r^{2}=.92, n=8, P \leqslant .01$ ).

To determine further whether or not the above joint probabilities fortuitously described or truly represented a moose's feeding behavior, the criteria were used to predict moose diets in other areas. Moose diets and food abundances were known for two areas with some of the same Isle Royale plant species: Superior National Forest, Minnesota (Peek et al. 1976) and La Verendrye Park, Quebec (Joyal 1976). As at Isle Royale (Belovsky and Jordan 1978), moose did not necessarily consume plants in proportion to their abundances in these two regions: i.e., they demonstrated preferences and aversions. For six plants also found 
at Isle Royale in winter (Corylus cornuta, Betula papyrifera, Abies balsamea, Sorbus americana, Amelanchier sp., Acer spicatum), the predicted and observed diets agreed quite well (Minnesota: $r^{2}=.88$, $n=6, P \leqslant .01 ;$ La Verendrye: $r^{2}=.92, n=5, P \leqslant$ $.01)$. Therefore, it appeared that the food selection criteria could be applied to other areas of different plant abundances and moose densities, suggesting that a moose 'strategy' had been delineated.

\section{Rationale for criteria}

Although the nutrient and item size criteria appeared to determine a moose's diet selection, what factors determined the minimum criterion values?

Minimum nutrient content $(N)$.- Minimum nutrient content, as demonstrated above (see Selection of nonpreferred plants), appeared to be related to a minimum plant digestibility required by moose, because in vitro dry matter digestibility was correlated with nutrient content for preferred plants. This did not imply that nutrient content determined digestibility per se; rather it appeared to be correlated with it. Furthermore, digestibility probably was difficult for a moose to assess, whereas a digestibility correlate which could be tasted or smelled by the animal might be selected for, and nutrient content might serve this function (see Westoby 1974 for review).

If there existed a minimum digestibility 'sought' by a moose, this value would be defined by the moose's daily metabolic demands and daily capacity to process food (rumen capacity in mass of food times its daily turnover rate). Both of these values were constraints in the moose diet optimization model published elsewhere (Belovsky 1978) and were fully described there. Combining these two feeding constraints, food plant digestibility $(D)$ must satisfy the inequality:

$$
D \geqslant \frac{M B}{V R_{f} K},
$$

where $M$ was the moose's metabolism (watts), $\mathrm{V}$ was the moose's rumen capacity (wet mass of food in grams), $R_{f}$ was the flow rate of food through the rumen (number of times the rumen empties per day), $K$ was the gross energy content of the food (megajoules per gram dry mass) and $B$ was the bulkiness of the food or the rate at which it filled the rumen (grams wet mass per gram dry mass). All of these parameters varied among seasons and among days within a season, and were presented for an average day within a season for simplification, enabling an approximate seasonal solution for $D$.

Because the minimum nutrient content, not digestibility, was empirically determined, a conversion was required to determine whether a computed minimum digestibility approached the empirical nutrient value. The in vitro digestibility-nutrient regression for preferred moose plants (Fig. 1) was not used for this conversion, because it was not known how in vitro and

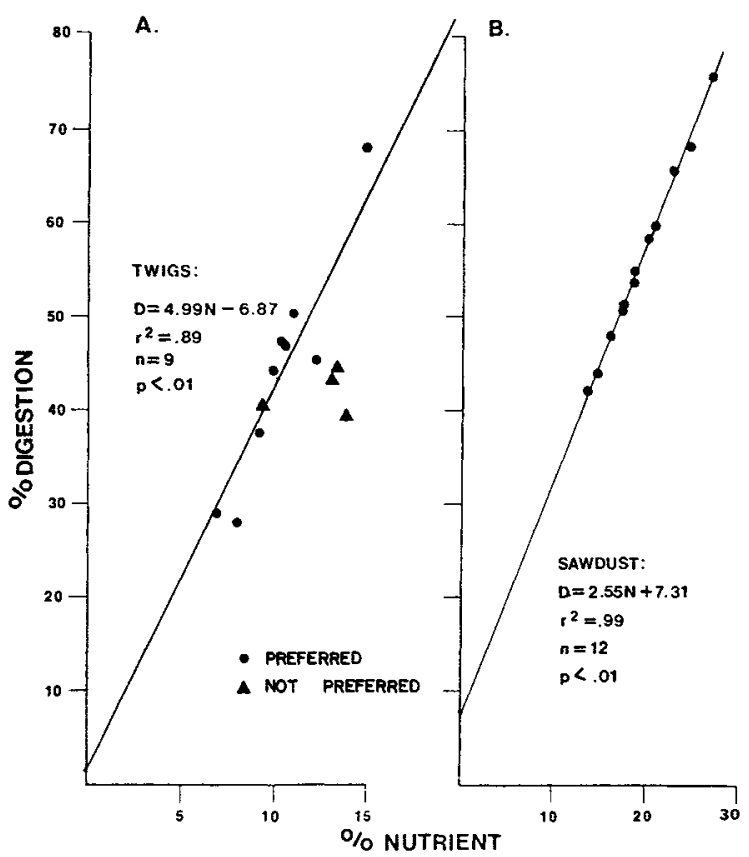

FIG. 2. Regressions of in vivo dry-matter digestibility by white-tailed deer (Odocoelius virginianus) against the nutrient content (ash + protein) of preferred winter foods A. (Ullrey et al. 1964, 1967, 1968, Mautz et al. 1974, Robbins et al. 1975); and nutrient-enriched sawdust B. (Amman et al. 1973). Similar results have been noted by others (Short et al. 1974, Robbins and Moen 1975).

in vivo values were comparable. Therefore, an in vivo digestibility-nutrient regression had to be developed for a species closely related to the moose, the whitetailed deer, because in vivo values were unavailable for moose. This was not to claim identity between deer and moose feeding, for certain differences were known. Deer did not have a preference for Abies balsamea (Ullrey et al. 1968) but moose did; however, the two species preferred many of the same plant species. Equating deer and moose digestion provided a first approximation for moose.

The in vivo digestion of preferred winter deer foods was regressed against nutrient content (Fig. 2a) (Ullrey et al. 1964, 1967, 1968, Mautz et al. 1974, Robbins et al. 1975). The nutrient content of pelleted sawdust mixed with protein and minerals and the observed digestion were also compared (Fig. 2B) (Amman et al. 1973). These regressions indicated that there existed a very close relationship between nutrient content and a deer's ability to digest foods, as was found for moose in vitro digestion (winter preferred plants: $r^{2}=.89$, $P \leqslant .01$; pelleted sawdust: $r^{2}=.98, P \leqslant .01$ ). If the sawdust were simply an indigestible compound, the positive correlation could reflect simple dependence of digestion on nutrient content. The regression slope, however, indicated a greater breakdown of the highcellulose sawdust than expected if sawdust were in- 
TABLE 5. The parameter values used in computing the theoretical $N$ and $I_{L}$ values.

\begin{tabular}{|c|c|}
\hline \multicolumn{2}{|l|}{ Metabolism (W) } \\
\hline $\begin{array}{l}\text { Summer (includes reproduction } \\
\text { and growth)* } \\
\text { Winterf }\end{array}$ & $\begin{array}{l}697.33 \\
557.96\end{array}$ \\
\hline $\begin{array}{l}\text { Aquatic macrophyte consumption } \\
\text { (g dry mass/summer } \mathrm{d})^{*}\end{array}$ & 868 \\
\hline \multicolumn{2}{|l|}{ Food Bulkiness (g wet mass/g dry mass) } \\
\hline $\begin{array}{l}\text { Aquatics* } \\
\text { Deciduous leaves* } \\
\text { Deciduous twigs } \dagger \\
\text { Conifer twigs } \dagger\end{array}$ & $\begin{array}{l}20 \\
4 \\
2 \\
2.5\end{array}$ \\
\hline \multicolumn{2}{|l|}{ Rumen capacity ( $\mathrm{g}$ wet mass $/ \mathrm{d}=\mathrm{VR}$ ) } \\
\hline $\begin{array}{l}\text { Summer } \\
\text { Winter } \dagger\end{array}$ & $\begin{array}{l}32900 \\
16450\end{array}$ \\
\hline \multicolumn{2}{|l|}{ Feeding time $(\min / \mathrm{d})$} \\
\hline $\begin{array}{l}\text { Summer } \$ \\
\text { Winter† }\end{array}$ & $\begin{array}{l}256 \\
590\end{array}$ \\
\hline \multicolumn{2}{|c|}{$\begin{array}{l}\text { Maximum number of food items consumed } \\
\text { per minute: }\end{array}$} \\
\hline $\begin{array}{l}\text { Deciduous leaves except Sorbus* } \\
\text { Sorbus leaves* } \\
\text { Twigs } \dagger\end{array}$ & $\begin{array}{r}128 \\
58 \\
25\end{array}$ \\
\hline \multicolumn{2}{|l|}{ Energy content of food ( $\mathrm{kJ} / \mathrm{g}$ dry mass $)$} \\
\hline $\begin{array}{l}\text { Deciduous leaves§ } \\
\text { Aquatic plants" } \\
\text { Twigs§ }\end{array}$ & $\begin{array}{l}17.6 \\
17.2 \\
17.6\end{array}$ \\
\hline \multicolumn{2}{|l|}{ Digestibility (\%) } \\
\hline Aquatic plants* & 94 \\
\hline
\end{tabular}

* Belovsky and Jordan 1978.

$\dagger$ G. E. Belovsky, personal observation.

\& Belovsky 1978

$\$$ Golley 1961.

"Boyd 1970.

digestible. The nutrient content enhanced the microorganism's fermentation of cellulose.

Using the average seasonal parameters in Table 5 and the regressions in Fig. 2 (for moose leaves, pelleted sawdust mixed with nutrients was substituted, as both food types had their nutrient content in a highly soluble form, unlike twigs; and for moose twigs, deer twigs were substituted), Eq. 1 was solved for the minimum digestibility required by moose for summer leaves, winter deciduous twigs and winter coniferous twigs. The computation of minimum digestibility for summer leaves required that the moose's metabolism and rumen processing capacity be reduced by the intake of aquatic vegetation, because a certain quantity of aquatics must be consumed to satisfy sodium requirements (Belovsky 1978, Belovsky and Jordan, in press). These computed minimum nutrient values compared quite well with the observed values (Table 6: $r^{2}=.99, n=3, P \leqslant .05$ ), suggesting that the observed nutrient criterion was a manifestation of the moose's 'attempt' to satisfy a minimum digestibility arising from food processing and metabolic constraints.

Minimum item size $\left(\mathrm{I}_{\mathrm{L}}\right)$.-Minimum item size $\left(I_{L}\right.$
TABLE 6. A comparison of the empirically determined and theoretical $N$ and $I_{L}$ values.

\begin{tabular}{lcc}
\hline \hline & $\begin{array}{c}\text { Theo- } \\
\text { retical }\end{array}$ & $\begin{array}{c}\text { Empir- } \\
\text { ical }\end{array}$ \\
\hline$N$ Values (\% mineral + protein): & & \\
Deciduous leaves & 23.8 & 27.3 \\
Deciduous twigs & 8.1 & 7.3 \\
Conifer twigs & 9.7 & 8.8 \\
$I_{L}$ (d dry mass): & & \\
Deciduous leaves except Sorbus & .12 & .10 \\
Sorbus leaves & .22 & .23 \\
Deciduous twigs* & .55 & .41 \\
Conifer twigs* & .46 & .30 \\
\hline
\end{tabular}

* These values were obtained by averaging each species' minimum mass, which was found by using the species' minimum diameter consumed by moose in a regression of diameter on mass for that species.

was defined from constraints utilized in the moose diet optimization model (Belovsky 1978): daily metabolic requirements and the moose's daily available feeding time. The item sizes selected by moose $(I)$ must satisfy the inequality:

$$
I \geqslant \frac{M}{T_{F} K R_{r} D},
$$

where $T_{F}$ was the maximum daily feeding time available to a moose, computed on the basis of a moose's thermal balance (in minutes per day: Belovsky 1981), $C$ was the moose's cropping rate (in items per minute), and $D$ was the minimum digestibility computed above (Eq. 1). Cropping rate was found to be independent of leaf or twig size and appeared to be primarily dependent upon the time to locate and remove individual items. As with the parameters used in computing minimum digestibility, Eq. 2's parameters varied among seasons, and the values presented in Table 5 represented an average day during the season, making the solutions for $I_{L}$ an average seasonal value. A comparison of the predicted and observed $I_{L}$ values (Table 6: $r^{2}=.92, n=4, P \leqslant .05$ ), suggested that the minimum item sizes selected by moose were related to their time-energy budgets.

Maximum item size $\left(\mathrm{I}_{H}\right)$.-Maximum item size $\mathrm{I}_{H}$ did not have a theoretical formulation, but it seemed likely that this limitation might have arisen from the moose's difficulty in biting off large twigs. If this were the case, a plant species' $I_{H}$ should be related to the strength of its wood. A rank correlation between five species' twig $I_{H}$ values and their wood's compression strengths suggested that these parameters were related (Table 7: $P \leqslant .05$ ). Abies balsamea and Thuja occidentalis were not included in the analysis, although compression strengths for their wood were available. Abies was not included because the two Isle Royale study sites did not have any Abies plants with twigs within reach of a moose yet too large for consumption. This absence of large Abies twigs was due to intensive 
moose feeding (Snyder and Janke 1976). Thuja was not included since moose were observed to feed upon the plant's 'plates' of needles rather than the twigs.

\section{Comparison with other foraging models}

Contingency models of optimal foraging.-These models (Schoener 1969, 1971, Pyke et al. 1977) differ from the model of food plant selection developed here. For animals such as moose which feed upon plants differing independently in digestibility and item size, a contingency model was written as:

$$
Q=\frac{\sum_{i} \sum_{i} \sum_{k} p_{i j k} u_{i, k}-C T_{s}}{\sum_{i} \sum_{i} \sum_{k} p_{i k k} t_{i}+T_{s}},
$$

where $Q$ was the quantity to be maximized (watts), $i$ referred to food items of species $i, j$ referred to items of digestibility $j, k$ referred to items of size $k$ in the diet (grams dry mass per item), $p_{i j k}$ was the proportion of the diet composed of items of $i, j$ and $k$ traits, $u_{i j k}$ was the net energy content of an item with $i, j$ and $k$ traits, $t_{i}$ was the cropping time for an item of food species $i$ (time per item), $c$ was the energetic cost for search, including metabolism per unit of time spent searching (watts), and $T_{s}$ was the time spent searching. $t_{i}$, as presented earlier, did not appear to depend upon item size or the digestibility of food items for moose.

The contingency model was a very complex relationship to solve for all $i, j$ and $k$ values which maximized $Q$. A simplification, however, was made which permitted the elimination of food plant species, $i$, as a pertinent trait. Using the summer feeding data presented in Tables 1 and 2 and assuming $T_{s}$ was a linear function of the proportion of food encountered and included in the diet, $q, Q$ was rewritten as:

$$
Q=\frac{\left(\sum_{j} \sum_{k} u_{i k} p_{i k}-0.13 / q\right) \mathrm{kJ} / \mathrm{item}}{(.01+.001 / q) \mathrm{min} / \mathrm{item}},
$$

where .01 was the value for $t_{i}$ in summer. Employing $.42 \mathrm{~kJ} /$ item increment classes for $u_{j k}$, starting with zero, $p_{j k}$ was computed such that $Q$ was maximized using the data presented in Tables 1, 2, and 3 and the regression equation in Fig. 2b. For moose summer feeding in the Yellow Birch forest in 1972, the most complete set of diet data, $Q$ was maximized only when items $\geqslant 0.84 \mathrm{~kJ} /$ item were included in the diet, while moose were observed to include only items which were $>1.3 \mathrm{~kJ} /$ item. Therefore, it appeared that moose did not follow a contingency model of feeding.

The contingency model of foraging had a moose, depending upon the relative abundances of food plants, changing the threshold values $N, I_{H}$ and $I_{L}$ to maximize energy intake per unit of time. In contrast, it was found in this study that moose appeared to have set threshold values. A moose processed approximately 20000 leaves/d when feeding optimally in sum-
TABLE 7. A ranking of the compression strength of several species of wood (average of parallel and perpendicular applied forces) in relation to the maximum twig size taken by moose $\left(I_{H}\right)$ to determine whether or not $I_{H}$ is related to the difficulty a moose encounters in biting off a twig. Compression values are from Betts (1919). The two coniferous species for which $I_{H}$ 's and compression strengths are known (Abies balsamea and Thuja occidentalis) were deleted for several reasons: (1) Moose normally do not eat Thuja twigs but the 'plate-like' needles; (2) Abies is so heavily browsed we cannot be certain that moose are not able to consume twigs larger than measured $I_{H}$. (3) Compression strength is measured on dried-cured wood, which may give a misconception of the conifers' strengths, since their resinous woods are quite 'rubbery' when fresh and difficult to break off.

\begin{tabular}{lcc}
\hline \hline & $\begin{array}{c}\hat{x} \\
\text { compression } \\
\text { strength } \\
\text { (M Pa) }\end{array}$ & $\begin{array}{c}I_{H} \\
(\mathrm{~mm})\end{array}$ \\
\hline Populus tremuloides* & 8.16 & 5.7 \\
Prunus pensylvanica* & 8.41 & 4.1 \\
Betula papyrifera & 8.68 & 3.9 \\
Acer spicatum & 12.58 & 4.4 \\
Betula alleghaniensis & 13.52 & 3.8 \\
Amelanchier sp. & 16.80 & 2.8 \\
\hline
\end{tabular}

* Data for these two species were collected from another Isle Royale forest type in the same manner used for the species and forest types in the text, because these two species did not occur in abundance on the forest types studied in this paper.

mer (Belovsky 1978); this perhaps presented too difficult a task for the moose's 'information-processing system' to integrate the data on digestibility and item size for each leaf. This difficulty could be avoided by implementing fixed thresholds which minimized the risk of selecting plants that did not satisfy energy requirements. Therefore, moose appeared to be 'risk averse'; Oaten (1977) pointed out this potential for animals where information processing capacity was restricted.

Because moose did not possess the 'perfect knowledge' required by contingency models, food was not utilized at maximum efficiency under conditions of food limitation, thereby reducing the potential population density. This reduced utilization was computed to be $30 \%$ (39\% utilization of summer plants under contingency model behavior vs. $9 \%$ utilization under the observed set-threshold behavior). This implied that a moose had a lower net energy intake each day than if it employed a contingency model approach to its foraging. These energy intake differences arose because at high food abundances a 'set-threshold moose' consumed, on average, plants of a lower energy content per unit of cropping time $(e / t)$ than a 'contingencybehaving moose.' At carrying capacity, however, the 'set-threshold moose' would ingest plants, on average, of higher energy content but requiring a greater search time, so the 'contingency-behaving moose' would still have a larger $e / t$ value. These differences were minimized, however, as moose foraging became more lim- 
ited by rumen processing capacity than feeding time, which might be the case at Isle Royale.

Other models. - Other models of herbivore foraging have been proposed by Westoby (1974) and Freeland and Janzen (1974). Westoby suggested the use of linear programming, the approach applied in a simpler form to predict successfully moose consumption of different plant classes (deciduous leaves, forbs and aquatic plants: Belovsky 1978). Westoby's approach, however, required $\mathrm{N}$ different plant species traits to explain the utilization of $\mathrm{N}$ species. The $\mathrm{N}$ traits included various absolute food abundance parameters, nutrients and toxins. Freeland and Janzen (1974) suggested that herbivores 'balance' the intakes of different plants with their differing toxic components to avoid overingestion of any one toxin. Both models of herbivore foraging (Freeland and Janzen 1974, Westoby 1974) were difficult to test because of the large quantity of data required.

The results presented in this paper indicated that these more complex approaches might be important in explaining which plant species a moose should utilize, but once utilization 'was decided upon,' the more simplistic nutrient-item size criteria predicted moose consumption quite well.

\section{Conclusion}

Using data collected on moose feeding, it was found that the nutrient content of plants, the size of food items and their relative abundances predicted a moose's feeding on preferred plant species quite well. When these criteria were applied to nonpreferred plants, it was found that some plants utilized by moose fit the nutrient-item size hypothesis, while many of the nonpreferred plants, which were almost never utilized (utilization $<1 \%$ ), were predicted to be utilized more than observed. This suggested that there might exist factors other than nutrient content-item size that excluded certain plants from the moose's diet. Toxicity, mineral concentrations and absolute food abundances, as suggested by Westoby (1974) and Freeland and Janzen (1974), might account for these species' exclusions; nevertheless, the simpler nutrient-item size criteria appeared to apply to the plants moose consumed.

The feeding model presented in this paper for moose food selection was in some ways comparable to the contingency model developed for carnivore and granivore feeding (Schoener 1971; Pyke et al. 1977), because both assumed simultaneous search for food items. But it appeared that moose were not capable of the contingency model's assumption of perfect knowledge, i.e., moose were unable to integrate all of the necessary information. The net result was that moose were unable to utilize their food resource to the fullest extent.

The model presented in this paper was different from that used to predict a moose's selection of food plant classes (Belovsky 1978), because that analysis assumed that each food class was searched for independently of the others. Consequently, there appeared to be two levels of moose feeding strategies. The first determined how nutritional requirements were optimally balanced in the allocation of rumen capacity and feeding time among food classes. The second level presented in this paper determined how a moose satisfied the alotted optimal intake of a food class among the different species composing the class.

\section{ACKNOWLEDGMENTS}

I wish to thank T. W. Schoener, C. R. Taylor, G. Orians, J. B. Slade, and D. Rhoades for reading early drafts of this paper and providing many helpful comments. I also wish to thank J. Cannon, L. Stowe, D. McEcheron, M. Tate, K. Hay, P. Spiro, W. Berliner, R. Bates, D. Johnson, D. Pletcher, and J. B. Slade for the long hours they donated as field assistants. The work was supported by a grant from the National Park Service to P. A. Jordan and D. B. Botkin and grants to the author from the Environmental Education Fund, The Richmond Society, Harvard University and The Harvard Society of Fellows. I also wish to acknowledge the aid provided by The National Park personnel at Isle Royale National Park, in particular, Superintendent H. Beattie, District Ranger D. Peterson and North Central Service Director R. Linn.

\section{Literature Cited}

Amman, A. P., R. L. Cowan, C. L. Mothershead, and B. R. Baumgardt. 1973. Dry matter and energy intake in relation to digestibility in white-tailed deer. Journal of Wildlife Management 37: 195-201.

Belovsky, G. E. 1978. Diet optimization in a generalist herbivore, the moose. Journal of Theoretical Population Biology 14:105-134.

- 1981. Optimal activity times and habitat choice of moose. Oecologia 48:22-30.

Belovsky, G. E., and P. A. Jordan. 1978. The time-energy budget of a moose. Journal of Theoretical Population Biology 14:76-104.

Belovsky, G. E., and P. A. Jordan. In press. Sodium dynamics and adaptations of a moose population. Journal of Mammalogy.

Betts, H. S. 1919. Timber: its strength, seasoning and grading. McGraw-Hill, New York, New York, USA.

Bissell, H. D., B. Harris, H. Strong, and F. James. 1955. The digestibility of certain natural and artificial foods eaten by deer in California. California Fish and Game 41:57-58.

Bissell, H. D., and W. C. Weir. 1957. The digestibilities of interior live oak and chamise by deer and sheep. Journal of Animal Science 16:476-480.

Boyd, C. E. 1970. Amino acids, protein and caloric content of vascular aquatic macrophytes. Ecology 51:902-906.

Freeland, W. J., and D. H. Janzen. 1974. Strategies in herbivory by mammals: the role of plant secondary compounds. American Naturalist 108:269-289.

Golley, F. 1961. Energy values of ecological materials. Ecology 42:581-584.

Joyal, R. 1976. Winter foods of moose in La Verendrye Park, Quebec: an evaluation of two browse survey methods. Canadian Journal of Zoology 54:1765-1770.

Kingsbury, J. M. 1964. Poisonous plants of the U.S. and Canada. Prentice-Hall, Englewood Cliffs, New Jersey, USA.

Longhurst, W. H., H. K. Oh, M. B. Jones, and R. E. Kepner. 1968. A basis for the palatibility of deer forage plants. Transactions of the North American Wildlife Natural Resources Conference 33:181-192. 
Mautz, W. W., H. Silver, and H. H. Hayes. 1974. Predicting the digestibility of winter deer browse from its proximate composition. Canadian Journal of Zoology 52:1201-1205.

Oaten, A. 1977. Optimal foraging in patches: a case for stochasticity. Journal of Theoretical Population Biology 12:263-285.

Pammel, L. H. 1911. A manual of poisonous plants. Torch Press, Cedar Rapids, Iowa, USA.

Peek, J. M., D. L. Urich, and R. J. Mackie. 1976. Moose habitat selection and relationships to forest management in northeastern Minnesota. Wildlife Monograph Number 48, Wildlife Society, Washington, D.C., USA.

Pyke, G. H., H. R. Pulliam, and E. L. Charnov. 1977. Optimal foraging: a selective review of theory and tests. Quarterly Review of Biology 52:137-154.

Radwan, M. A. 1972. Differences between Douglas-fir genotypes in relation to browsing preference by black-tailed deer. Canadian Journal of Forest Research 2:250-255.

Radwan, M. A., and D. L. Campbell. 1968. Snowshoe hare preference for spotted catsear flowers in western Washington. Journal of Wildlife Management 32:104-108.

Radwan, M. A., and G. L. Crouch. 1974. Plant characteristics related to feeding preference by black-tailed deer. Journal of Wildlife Management 38:32-41.

Robbins, C. T., and A. N. Moen. 1975. Composition and digestibility of several deciduous browses in the Northeast. Journal of Wildlife Management 39:337-341.

Robbins, C. T., P. J. VanSoest, W. W. Mautz, and A. N. Moen. 1975. Feed analyses and digestion with reference to white-tailed deer. Journal of Wildlife Management 39:67-79.

Schoener, T. W. 1969. Models of optimal size for solitary predators. American Naturalist 103:277-313.

. 1971. Theory of feeding strategies. Annual Review of Ecology and Systematics 2:370-404.

Short, H. L., R. M. Blain, and C. H. Segelquist. 1974. Fiber composition and forage digestibility by small ruminants. Journal of Wildlife Management 38:197-209.

Snyder, J. D., and R. A. Janke. 1976. Impact of moose browsing on boreal forests of Isle Royale National Park. American Midland Naturalist 95:79-92.

Swift, R. W. 1948. Deer select most nutritious forages. Journal of Wildlife Management 12:109-110.

Ullrey, D. E., W. G. Youatt, H. E. Johnson, R. K. Ku, and L. D. Fay. 1964. Digestibility of cedar and aspen browse for the white-tailed deer. Journal of Wildlife Management 28:791-797.

Ullrey, D. E., W. G. Youatt, H. E. Johnson, L. D. Fay, and B. E. Brent. 1967. Digestibility of cedar and jack pine browse for the white-tailed deer. Journal of Wildlife Management 31:448-459.

Ullrey, D. E., W. G. Youatt, H. E. Johnson, L. D. Fay, B. E. Brent, and K. E. Kemp. 1968. Digestibility of cedar and balsam fir browse for the white-tailed deer. Journal of Wildlife Management 32:162-171.

Westoby, M. 1974. An analysis of diet selection by large generalist herbivores. American Naturalist 108:290-304. 